https://doi.org/10.31470/2706-7904-2021-16-151-154

\title{
ОБРАЗ ЛЮДИНИ ТА ІНФОСВІТУ В КОНТЕКСТІ ПРОЄКТИВНОЇ ЛІНГВІСТИКИ
}

\section{Human Image and the Information World in the Context of Projective Linguistics}

\author{
Vasyl Kremen \\ Dr. Sc. in Philosophy, Professor \\ National Academy of Educational Sciences of Ukraine \\ president@naps.gov.ua \\ https://orcid.org/0000-0001-5459-1318 \\ Volodymyr Ilyin \\ Dr. Sc. in Philosophy, Professor \\ Taras Shevchenko National University of Kyiv (Ukraine) \\ ilin_vv@ukr.net \\ https://orcid.org/0000-0003-0503-8545
}

\begin{abstract}
The article is devoted to the psycholinguistic aspect of the analysis of the new image of the world generated by the dominant influence of digital culture, and the formation of a new human image in the context of changing ways of communication and language conversation. The problem of human existence in the infosphere, which generates a new image of man (homo digitalis), is considered. The image of the world in psycholinguistics, presented to a person through system of the subject values which appear its structural elements, is conceptualized. Psycholinguistic analysis of the "image of the world" and the "image of a human" opens up prospects for the active entry of modern culture of speech and communication in the parameters of the new era.
\end{abstract}

Keywords: world image, informational world, homo digitalis, projective linguistics, psycholinguistics.

\section{Вступ \\ Introduction}

Кожна епоха створювала свій образ світу, орієнтиром у якому була мова як система комунікації, передачі знань і потрібної інформації. Мова у взаємозв’язку зі свідомістю та мисленням постає способом внесення тієї чи іншої корекції в образ світу співрозмовника - «великого», або глобального, і «малого», або реального світу, що переживається людиною. 3 іншого боку, таке єдине розуміння реальності, а також узгодженість дій у ній мають своєю передумовою можливість адекватного 
спілкування. Психолінгвістика має значний досвід моделювання ситуативної взаємодії образів людини та світу, у напрямі побудови «психолінгвістики діяльної взаємодії» (Леонтьев, 2003: 276). Водночас потрібно враховувати факт виникнення дигітальної культури, що тримається на «інформаціональності», та позбавлена належної вербальної комунікації. Проникнення «дигітального сущого» (Cappuro, 2017: 9) в основи життя формує дигітальну людину (homo digitalis), iснування якої здійснюється в симулякрах віртуального, відокремленого від реального світу 3 відповідною системою мовної комунікації. В даному контексті важливо виявити можливості проєктивної лінгвістики, яка досліджує систему нових способів мовного спілкування і водночас є психолінгвістичною сутністю мовних норм homo digitalis як моделі нового образу людини.

\section{Методи та методики дослідження Methods and Techniques of the Research}

Для визначення предмета аналізу проведено системний огляд психолінгвістичних, соціально-філософських, культурологічних, психологічних наукових джерел, безпосередньо дотичних до поставлених питань. Головні теоретико-методологічні позиції узагальнені на грунті контамінаційного методу у вимірах психолінгвістичної концепції образу світу в аспектах дигітальної культури, яка корелює з образом дигітальної людини. Конкретизація поставленого завдання потребувало залучення аналітико-системного методу, що дало змогу розкрити проблему взаємовідношення і зв'язків між зовнішньою, практичною, і внутрішньою, когнітивною діяльністю. Формування мисленнєвої дії на засадах сприйняття й аналізу зовнішніх матеріальних процесів із предметами та образами оточуючої реальності, що утворює як нову комунікативну систему спілкування і передачі інформації, так i образ нової людини, проведено на грунті структурно-функціонального підходу. У процесі дослідження особливостей формування образу дигітальної людини (homо

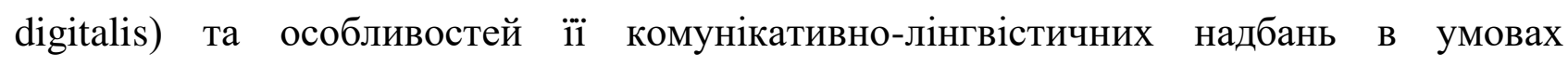
інформаційно-цифрового суспільства, його креативного потенціалу, і пов'язаних 3 ним деструкцій і ризиків було задіяно метод проєктивної лінгвістики.

\section{Результати \\ Results}

Найважливішим проектом віртуального світу, або інфосфери, є нова людина, інтермен, життя якого тісно пов'язане 3 Інтернетом. За характером соціальної діяльності, завдяки новаторському існуванню ця людина набуває креативності, 
оскільки на чільне місце виходить активність у блогосфері, самоконструюванні та побудові нового образу «Я», що відповідає новій, соціальній реальності, основним драйвером якої стала дигітальна культура. Вона є основою творення нового образу світу, презентованого кожному індивіду через предметні смисли, як би «накладені» на його сприйняття. Тепер людина не «номінує» чуттєві образи предметів, оскільки предметні значення є «компоненти цих образів, те, що їх цементує для людини, те, що робить можливим саме існування цих образів» (Леонтьев, 2003: 269). Створені в інформаційно-цифровому просторі образи людини як людини homo digitalis відрізняються від homo creator, яка здійснила самостворення себе й оточуючої реальності. Homo digitalis $є$ конструктом людини, яка здійснила «гіперкомпенсацію своєї недостатності, але набула статусу постійно переміщуваної особи, доля якої запрограмована та визначається дотиком пальця користувача до монітора» (Култаєва, 2020: 31).

У результаті для homo digitalis здатність орієнтації у світі позбавляється сенсу, оскільки духовно-смислове спілкування зі світом втрачає свою культурно-буттєву реальність. Так само як для homo digitalis палець здатен замінити будь-які знаряддя для письма, що призводить до того, що не обов'язково вміти писати, так само відпадає необхідність активного мовного спілкування, оскільки епоха Метамодерну формує нові смисли, які не можна передати мовою попередніх епох. У ній істина недосяжна, оскільки єдино істинним постає гранична об'єктивна реальність, що не дана нам у своїй повноті. Ми ніколи не зможемо досягти цієї реальності, абстрактно (мисленнєво чи духовно) потрапляємо в заблудження, оскільки не маємо інструменту верифікації. Усе постає крізь призму суб’єктивності, оскільки суб’єкт пізнання має обмеження в силу своєї обумовленості формою буття. Тому духовно-ціннісне втрачає своє значення, а разом з ним - усе, що традиційно входило в нього, зокрема й осмислена мова спілкування. Людина епохи Премодерну і Модерну орієнтувалася на смисл і шукала його. Людина епохи Премодерну прагнула до вічних цінностей; в епоху Модерну вона прагнула перетворити світ завдяки раціональності; в епоху Постмодерну смисл втрачається, що стає причиною виникнення деконструкції, перформансу, симулякру, нігілізму. Людина епохи Метамодерну, відчуваючи тугу за смислом, прагне до відтворення доцільності світу та людини, тобто себе, в ньому (Cappuro, 2017; Shabanova, 2020).

В силу чого потрібна нова мова, адже спілкування насамперед $є$ способом внесення тієї чи іншої корекції в образ світу співрозмовника - конкретний, ситуативний, фрагментарний і водночас безпосередній. Відповідно «засвоєння нової мови $\epsilon$ переходом на новий образ світу, необхідний для взаєморозуміння i співробітництва з носіями цієї іншої мови та іншої культури» (Леонтьев, 2003: 272). 
Сучасна епоха демонструє новий образ світу й образ нової людини. Причому за своїм змістом вони кардинально відрізняються від образів попередніх епох, оскільки вплив дигітальної культури постійно зростає, що ускладнює життя в усіх його аспектах. Для його розуміння потрібен проєктивно-лінгвістичний підхід до мови, який передбачає множину відгалужень, що розходяться в усі боки від традиційного способу мовного спілкування. Завдання проєктивної, творчої лінгвістики полягає у вилученні всього «живого», когнітивно-психологічно близького нормам сучасного буття, тим самим наблизивши новий образ людини до викликів і вимог нового образу світу.

\section{Висновки Conclusions}

Психолінгвістичний аналіз «образу світу» i «образу людини» відкриває перспективи активного входження сучасної культури мовлення та спілкування в параметри нової епохи. Її драйвером постає дигітальна культура, результатом якої $\epsilon$ факт ствердження дигітальної людини (homo digitalis), що зумовлює виникнення культурних інновацій і пов'язаних з ними освітніх, інтелектуальних, лінгвістичних, епістемних трансформацій. Діяльність і життєтворчість людини в трендах дигітальної культури має схильність до квазіраціонального обгрунтування комп'ютерної грамотності. Це приводить до втрати культури мовлення та спілкування. На сучасному етапі, потрапивши в жорсткі параметри інформаційних спокус, які дедалі більш широко надає мережа та Інтернет і демонструє дигітальна культура, людина стала Інтерменом. Для повернення людини у сферу продуктивної діяльності потрібно реалізувати підходи проєктивної лінгвістики, яка сприяє перетворенню мови, виявленню iï структурних і смислових можливостей, розширенню іï лексичної, граматичної, концептуальної системи в умовах дигіталізації всіх сфер життя. Їх психолінгвістичні обгрунтування мають стати важливим кроком у цьому напрямі.

\section{Література \\ References}

Култаєва, М. (2020). Ноmo digitalis, дигітальна культура і дигітальна освіта: філософськоантропологічні розвідки. Філософія освіти, 1(26), 8-36. https://doi.org/10.31874/2309$\underline{1606-2020-26-1-1}$

Леонтьев, А.А. (2003). Основы психолингвистики. (3-е изд.). Москва: Смысл; Петербург: Лань.

Cappuro, R. (2017). Homo digitalis. Beitrdge zur Ontologie, Anthropologie und Ethik der digitalen Technik. Berlin: Springer. https://doi.org/10.5771/0010-3497-2018-1-97

Shabanova, Yu.O. (2020). Metamodernism Man in the Wordview Dimension of New Cultural Paradigm/Anthropological Measurements of Philosophical Research, 18, 121-131. https://doi.org/10.15802/ampr.v0i18.221402 